\title{
COMMUNITY EMPOWERMENT TOWARDS ENERGY SAVING OF SETTLEMENT AT RT.03 / RW.01 KEL. PETUKANGAN UTARA KEC. PESANGGRAHAN JAKARTA SELATAN
}

\author{
Eka Purwa Laksana, Nifty Fath, Anggaraeni Dyah Sulistiowati, Harfa Iskandaria \\ Universitas Budi Luhur, Indonesia \\ eka.purwalaksana@budiluhur.ac.id
}

\begin{abstract}
Dense settlements in urban areas are one of the problems in DKI Jakarta. RT.03 / RW.01 Kel. Petukangan Utara, Kec. Pesanggrahan Jakarta Selatan is one of the densest settlements in DKI Jakarta which is located side by side with Universitas Budi Luhur. Based on SNI 03-1733-2004, the level of population density in the region is included in the category of High Density. This can be seen from the houses lined up along the road with little provision of Green Open Space. The community develops the need for building area by maximizing the area of land for building. This impacts the lack of air circulation in accordance with SNI-14-1993-03 about the thermal comfort area of buildings which are conditioned for Indonesians, as well as the lack of lighting in accordance with SNI 03-6575-2001 regarding illumination standards for the light of a room.With thermal comfort and illumination that is not in according to standards in the region, a Community Service activity was held by the Faculty of Engineering of the Universitas Budi Luhur to add community knowledge about how to make thermal comfort and illumination in homes using energy efficient. Thermal comfort can be fulfilled by making vertical greening on limited land, While the comfort of illumination can be fulfilled by using LED lights. The activity uses community empowerment methods, so that the community can independently make vertical greening in their respective homes and know the benefits for thermal comfort and can use LED lights in their respective homes and know the benefits to save electricity. The results of the Community Empowerment Towards Energy Saving Settlements at RT.03 / RW.01 Kel Petukangan Utara Kec. Pesanggrahan Jakarta Selatan, is that the region has vertical greening as a natural air conditioning system and uses an LED lighting system as an energy efficient lighting.
\end{abstract}

Keywords: LED Energy Saving Lamp, Community Empowerment, Vertical Greening, Natural Air Conditioning, Dense Settlement.

\section{INTRODUCTION}

The rate of population growth affects the increasing need for settlements in urban areas, while the area of land in urban areas does not increase. The speed of population growth should be balanced with the speed of providing residential facilities. finally, densely populated settlements show with increasing population. Various problems in densely populated settlements arise due to the lack of supporting facilities and infrastructure. In addition, densely populated settlements often cause environmental problems and reduce quality of life.

One of the densely populated settlements in DKI Jakarta that is close to the location of Universitas Budi Luhur is RT.03/RW.01 Kel Petukangan Utara Kec Pesanggrahan Jakarta Selatan. This area is categorized as included in densely populated settlements due to the density of residents and the density of buildings in the settlement. One characteristic of densely populated settlements is the limited land in each residence. The area of residential land is maximized for buildings, not infrequently violations of the availability of Green Open Space occur in almost all residences. The loss of green open space has an impact on the loss of water infiltration which can cause flooding, as well as the loss of greening that serves as a buffer against urban air pollution. Dense population settlements become part of neighborhoods that are not environmentally friendly in urban areas. Environmentally friendly settlements are green or sustainable concept settlements. Environmentally friendly settlements are steps to respond to environmental problems in densely populated settlements found in urban areas. The design of environmentally friendly settlements or green settlements is settlements with a green environment (there are protective vegetation, boundaries, creepers and ground cover). Zero waste settlement does not produce waste that pollutes the environment, so it must have a waste management and water management system independently. Physically the building and environment must also pay attention to the rules of a healthy home, healthy environment, save energy and use renewable building materials.

Therefore, community empowerment activities at RT.03 / RW.01 Kel Petukangan Utara Kec Pesanggrahan Jakarta Selatan is very much needed. In this activity the community will be given knowledge to provide vertical greening on limited land. Vertical greening functions as a natural air conditioner in buildings, so it can save energy use for artificial air conditioning. In addition, the public will also be given knowledge about the use of LED lights for homes. LED lights can also save the use of electrical energy for lighting. In the end the 
community environment RT.03 / RW.01 is expected to become an environmentally friendly settlement in DKI Jakarta.

\section{A. The Problem}

Community problems at RT.03 / RW.01 Kel Petukangan Utara Kec Pesanggrahan Jakarta Selatan is the lack of public knowledge to create a vertical greening system on limited land and the benefits of greening as natural air conditioning and the use of energy saving lamps. This can be seen from the habit of people who still have the mindset that greening can only be applied to open land without pavement. In addition, people also still have the mindset that LED lights are more expensive than flourence lamps, even though they are labeled as energy saving lamps.

\section{B. Target}

The resulting output target is for the community to know how to create a vertical greening system on a limited area that functions as a natural air conditioner in a residential home and to find out the benefits of LED lights that can save the use of electricity.

\section{GENERAL DESCRIPTION OF TARGET COMMUNITIES}

\section{A. Profile of Target Communities}

The total area of RT.03 / RW.01 Kel Petukangan Utara Kec Pesanggrahan Jakarta Utara is \pm 1 Ha with a total of 120 residential buildings. The population is 300 people with 120 families. Regional boundaries are as follows:
North borders
: RT.04 / RW.01
East bordereds
: Pesanggrahan river
South borders
: RT.01 / RW.01
West borders
: Sulaiman street

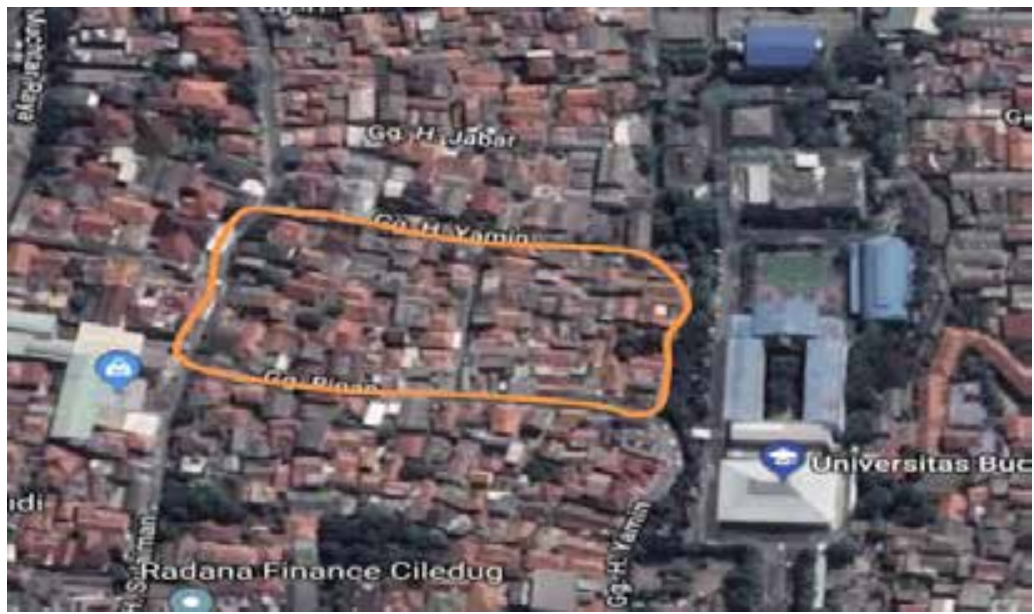

Picture 1. Area Map of Rt 03 / RW 01 Kel Petukangan Utara Kec Pesanggrahan Jakarta Selatan

\section{B. Condition of Object of Community Service Activities Dense Population Settlements}

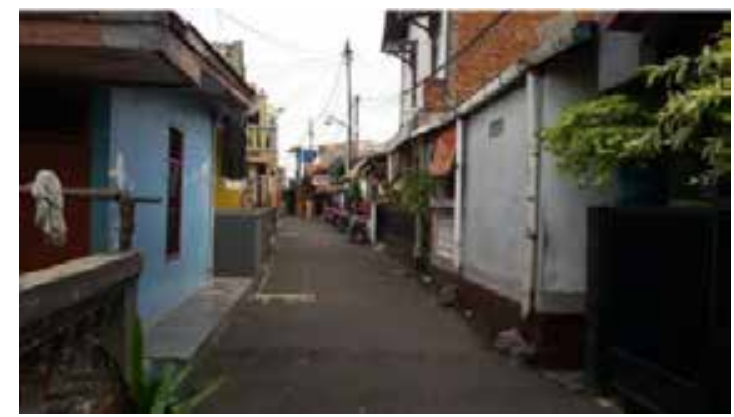

Picture 2. Condition of residential areas RT.03/RW.01 
Population density can be seen in houses lined up along the road. The width of the neighborhood road is $1 \mathrm{~m}$ to $1.5 \mathrm{~m}$.

\section{Greening in Residential Houses}

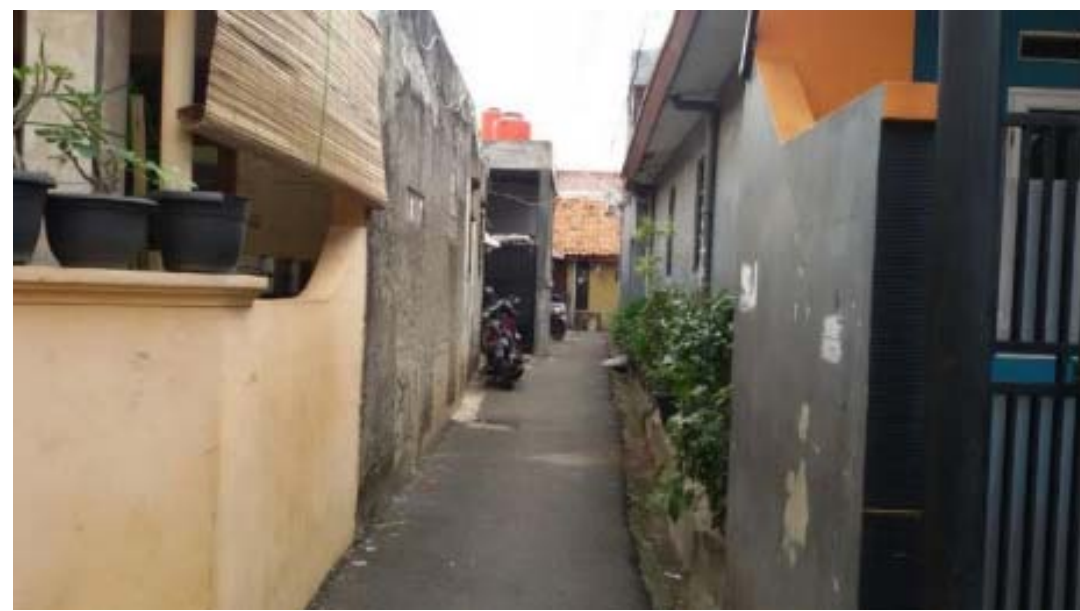

Picture 3. Change the function of a green open space into a building at RT.03/RW.01

The limited land in a residential house has an impact on the expansion of space requirements built on open green space. This results in the loss of greening in the neighborhood.

\section{Use of fluorescent lamps}
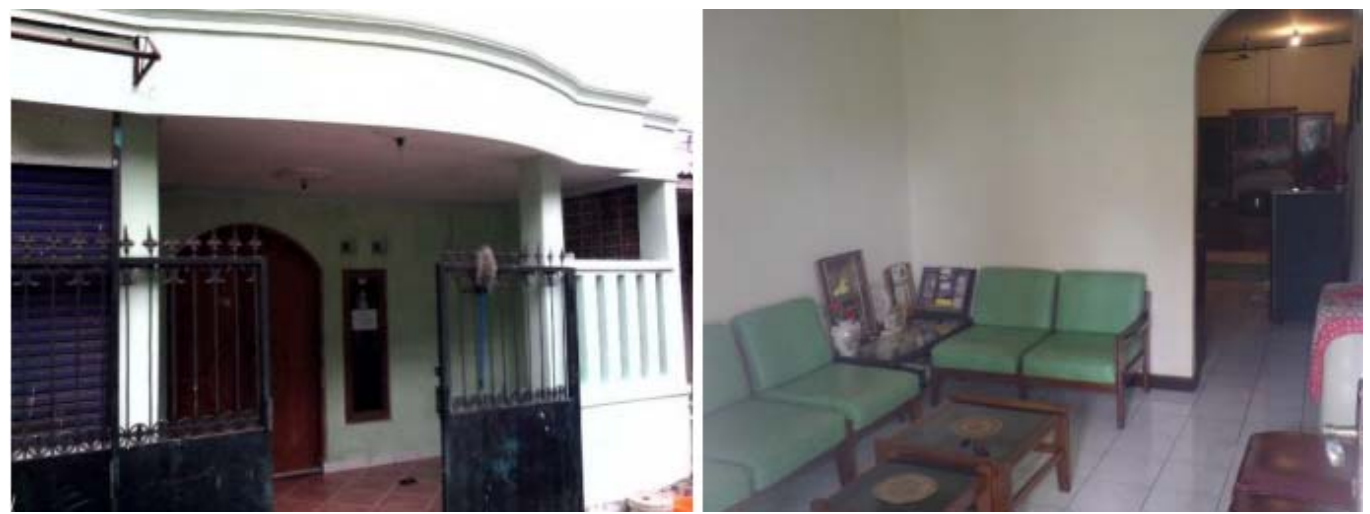

Picture 4. using Lampu Flourence lamp at home at RT.03/RW.01

\section{METHOD OF IMPLEMENTATION}

To engage directly the community in the effort to implement Community Empowerment Towards EnergySaving Settlements in RT.03 / RW.01 Petukangan Utara Village, Pesanggrahan Subdistrict, South Jakarta, an approach process with the TRI-DAYA concept is needed.

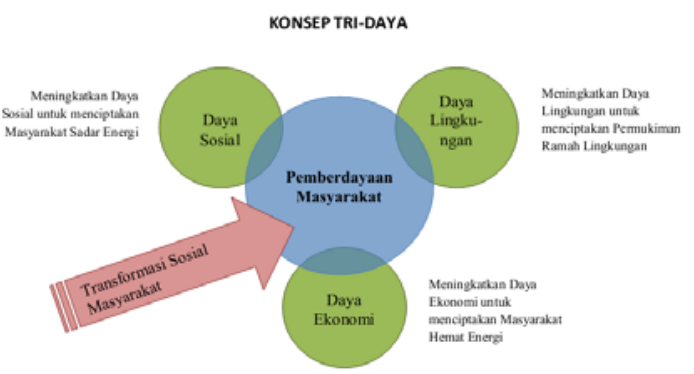

Picture 5. Chart the Concept of Community Empowerment Towards Green Settlements at RT.03/RW.01 


\section{A. Social Power}

The concept of Social Power is empowerment towards an energy conscious community through:

1. Knowledge of the benefits of greening as a natural air conditioner in the home.

2. Knowledge of the benefits of energy saving lamps on rum

\section{B. Environmental Power}

The concept of Environmental Power is community empowerment to create environmentally friendly settlements through:

1. Vertical greening on limited land.

2. Greening using a pot of materials that can be reused.

3. The use of LED energy-saving lamps in residential homes.

\section{Economic Power}

The concept of Economic Power is community empowerment to make vertical greening as natural air conditioning in their respective homes, so as to save costs for the use of energy for artificial air conditioning. In addition, community empowerment to use LED energy-saving lamps as lighting in their respective homes, so they can save on electricity usage.

\section{RESULT}

The results of the implementation of Community Empowerment Towards Energy Saving activities for the community RT.03 / RW.01 Kel Petukangan Utara Kec Pesanggrahan Jakarta Selatan are increasing knowledge about creating a vertical greening system on limited land that functions as a natural air conditioner in residential homes and increasing knowledge about the benefits LED lights that can save electricity usage.

\section{A. Air Conditioning Plant Training}

Due to the lack of public knowledge about some ornamental plants that can be useful to cool the air, training was held on ornamental plants that can cool the air for the community RT.03 / RW.01 Kel Petukangan Utara kec Pesanggrahan Jakarta Selatan. By holding training on ornamental plants that can cool the air and provide souvenirs in the form of ornamental plants, the community can immediately apply them in their respective homes. In the end, the air in each house becomes cooler so that it can save energy use for artificial air conditioning. From this training the community is expected to develop a culture to plant ornamental plants that can cool the air in their respective homes, and transmit them to the surrounding community. Planting ornamental plants that can cool the air in each home will become a culture in the community RT.03 / RW.01 Kel Petukangan Utara Kec Pesanggrahan Jakarta Selatan.

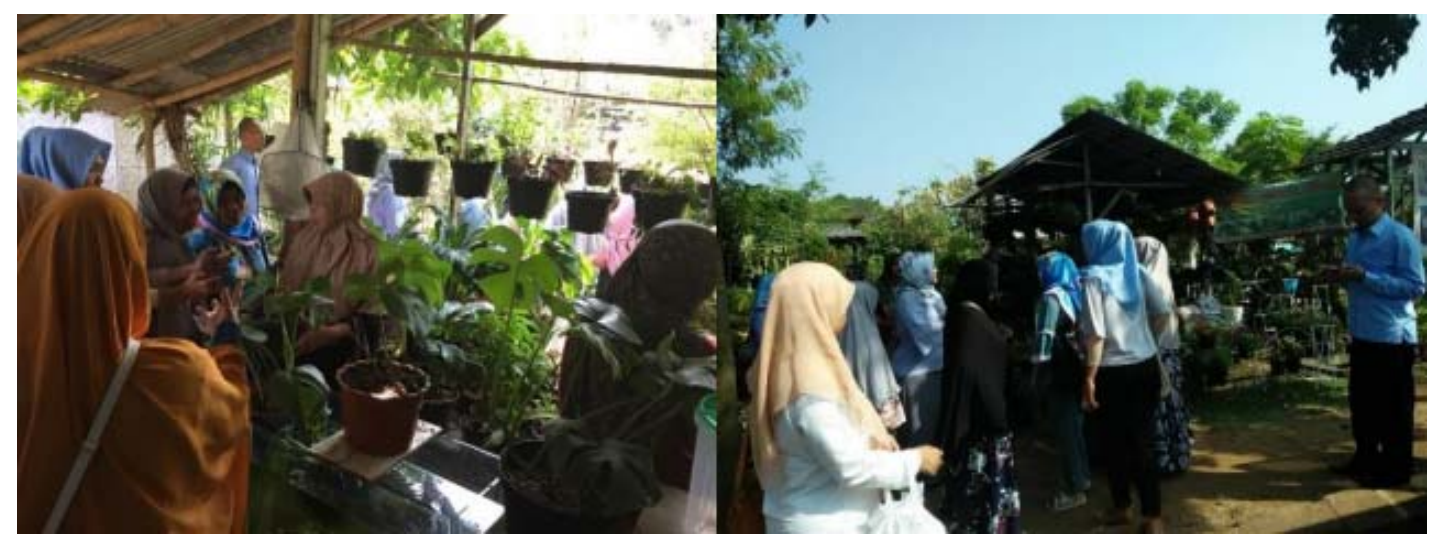

Picture 6. Ornamental Plant Training for Air Conditioning at Graha Raya

\section{B. LED Energy Saving Lighting Training}

People still think that LED lights are more expensive and there are still a few variations of the brands in the market compared to flourense lamps that are more affordable and the many choices of brands available on the market ranging from cheap to expensive. Thre a training on the benefits of LED lights that are more energy 
efficient for the community RT.03 / RW.01 Kel Petukangan Utara Kec Pesanggrahan Jakarta Selatan. With the holding of training on the benefits of LED lamps that are more energy efficient and give Door Prize prizes in the form of LED lights, the community can directly use the LED lights in their respective homes.

After the community gets the knowledge about the benefits of LED lamps that are more energy efficient and feels the benefits directly after using the LED lights, this will be transmitted to the community in their environment. Thus the use of LED lights instead of the usual flourense lamps will become a new culture for the people of RT.03 / RW.01 Kel Petukangan Utara Kec Pesanggrahan Jakarta Selatan.

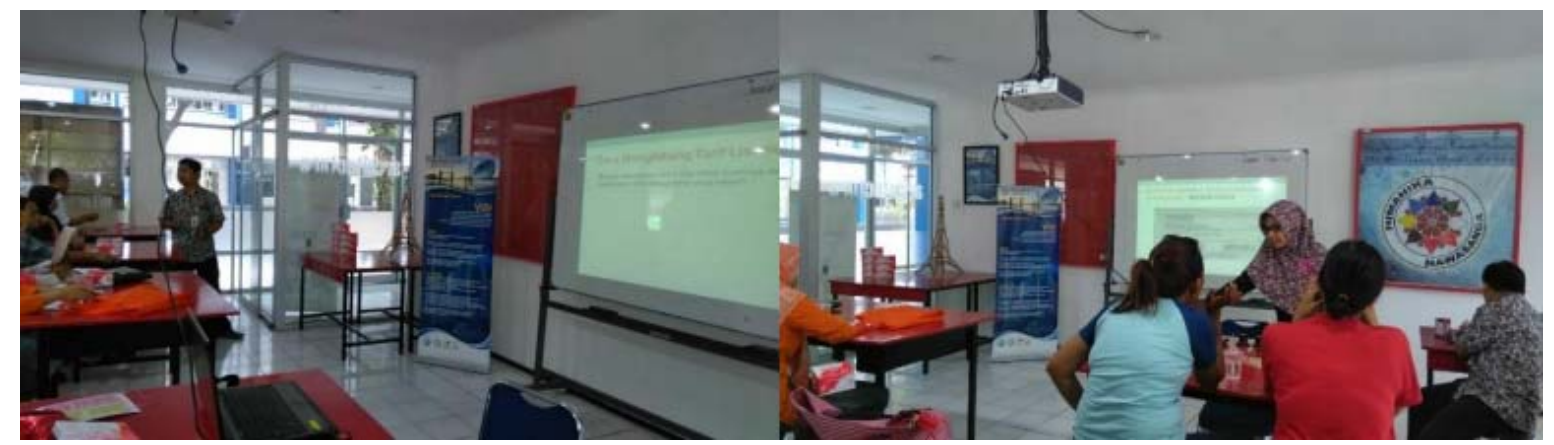

Picture 7. Training Energy Efficient Lighting using LEDs

\section{Training in Making Vertical Greening with Used Materials}

Due to the limitations of open land in their respective homes, it is rarely found greening the community environment in RT.03 / RW.01 Kel Petukangan Utara Kec Pesanggrahan Jakarta Selatan. Though reforestation can also be applied to limited land. Thus the training was held to make vertical greening on limited land, by using potting media from reusable materials. By applying vertical greening on each residence, the water in the residence becomes cooler so that it can save energy use for artificial air conditioning.

After the community makes vertical greening by using potting media from materials that can be reused in their respective homes, this will spread to the surrounding community. In the end, vertical greening on limited land by utilizing materials that can be reused as a media pot, will become a culture in the community RT.03 / RW.01 Kel Petukangan Utara Kec Pesanggrahan Jakarta Selatan

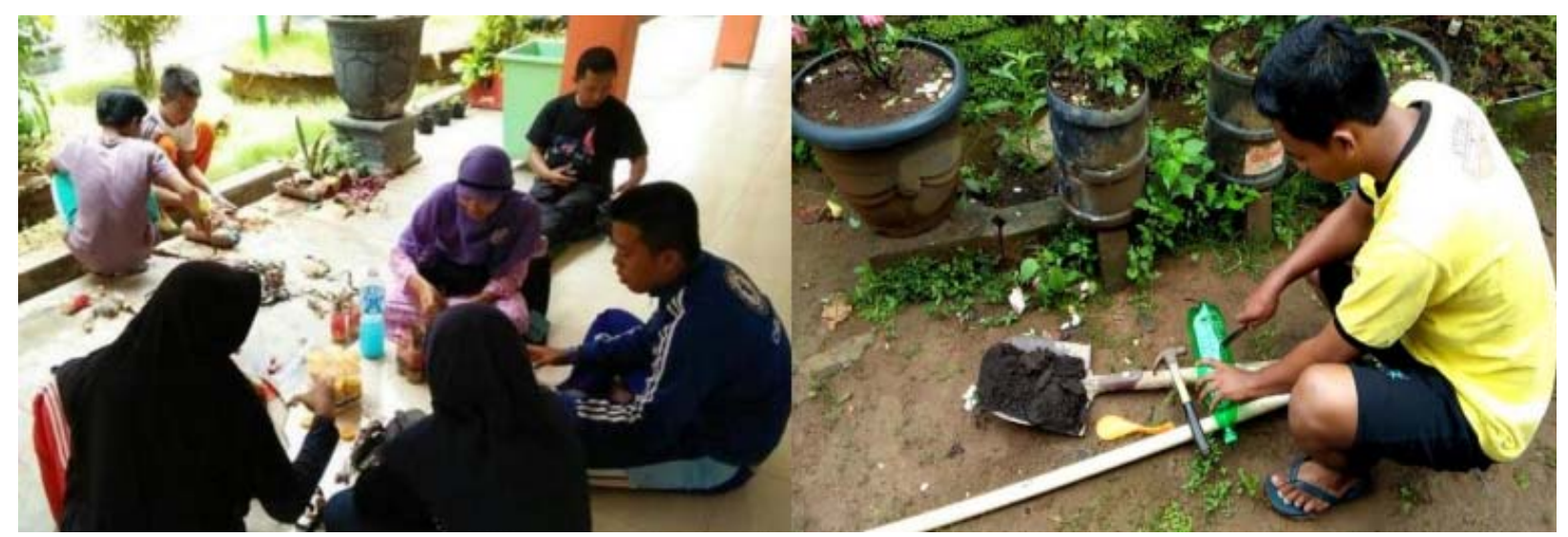

Picture 8. Training in Making Vertical Greening with Used Materials

\section{Discussion}

With the Community Service Program carried out by the Faculty of Engineering of the Universitas Budi Luhur through Community Empowerment Towards Energy Savings for the Community RT.03 / RW.01 Kel Petukangan Utara Kec Pesanggrahan Jakarta Selatan, the community already has knowledge about ornamental plants that are useful as air conditioning, LED energy saving lamps and vertical greening on limited land by utilizing materials that can be reused as pot media. With this knowledge, it is hoped that the community can start saving energy use for artificial air conditioning and illumination in their respective homes. Thus the community begins to implement an air conditioning system through ornamental plants that are planted vertically on the walls 
of the house and use LED lights, so the community will reduce the use of electrical energy in their respective homes. In the end the community environment RT.03 / RW.01 Kel Petukangan Utara Kec Pesanggrahan Jakarta Selatan became an energy-efficient environment.

\section{CONCLUSIONS}

RT.03 / RW.01 kel Petukangan Utara Kec Pesanggrahan Jakarta Selatan is one of the densely populated settlements in DKI Jakarta. This area is categorized as included in densely populated settlements due to the density of residents and the density of buildings in the settlement. The limited land in residential areas is due to the maximization of land area used for buildings, resulting in violations of the availability of Green Open Space in almost all residences. In addition, physical buildings and the environment also pay less attention to the rules of saving energy.

By training ornamental plants that can cool the air, LED energy saving lamps and vertical greening on limited land by using materials that can be reused for potting media, the community RT.03 / RW.01 Kel Petukangan Utara kec Pesanggrahan Jakarta Selatan can save energy use electricity in each other's homes.

\section{REFERENCES}

Suryandari, Putri; Dyah, Anggraeni dan Kurniasih Sri. 2017. IbM Menuju Kampung Petani Sampah di Kampung Belakang Kelurahan Kamal Kecamatan Kalideres Jakarta Barat. Laporan PKM. Universitas Budi Luhur Jakarta.

Kurniasari, Netty Dyah. 2015. Program CSR Berbasis Pemberdayaan Masyarakat (Untuk meningkatkan Produktivitas Usaha Mikro, Kecil, Menengah di Madura). Jurnal NeO Bis. Volume 9 No.1 2015.

Sugiyono. 2011. Metode Penelitian Kuantitatif, Kualitatif, dan R \& D. Bandung: Alfabeta.

Perkotaan, PNPM Mandiri. Pedoman Teknis Kegiatan Tri Daya (Sosial, Ekonomi, dan Lingkungan), Direktorat Jenderal Cipta Karya - Kementerian Pekerjaan Umum. 